\title{
AUTOMATA AUTÓPÁLYA KÖRIDŐ MÉRŐ ESZKÖZ FEJLESZTÉSE NI ESZKÖZ FELHASZNÁLÁSÁVAL
}

\section{DEVELOPING AN AUTOMATED LAP TIME MEASUREMENT SOLUTION USING NI EQUIPMENT}

\author{
Dombi Kristóf Barnabás \\ Debreceni Egyetem Müszaki Kar Mechatronikai Tanszék, Debrecen, Magyarország \\ kristof.barnabas1996@gmail.com
}

\begin{abstract}
Nowadays, we encounter with automation all around us. Let it be at work, industry, public places, our homes, or handheld devices, we just cannot miss it. This rapidly developing world, machines are continuously replacing human workforce, due to their superior load bearing, and the absence of loss of concentration, accuracy, speed or efficiency, which makes them surpass manpower in many fields. In this project, I'll present an automated lap time measurement system, built using NI components, which will save the voltages tied to the lap time, measures human and machine times, which data will be later compared and evaluated.
\end{abstract}

Keywords: myDAQ, LabVIEW, Comparison, measurement, data processing .

\section{Összefoglalás}

Az életünk szinte minden területén találkozunk automatizálással. Legyen szó akár munkahelyről, közterületekről, otthonaikról vagy sajátkészülékeinkről. Ebben a gyorsan fejlődő világban nagyon sok esetben a gépi munka felváltja az emberi munkát. Nagyon sok esetben a gép felülkerekedik az emberen legyen szó akár fizikai monotonitásról, elfáradásról, koncentrációról, pontosságról, gyorsaságról, teljesítményről. Dolgozatomban ismertetek egy olyan automata köridő mérő rendszert, NI (National Instrument) eszköz felhasználásával, mely elmenti a felhasználó kör idejéhez tartozó feszültség változásokat. Méri a rendszer a gépi és emberi köridőket is, majd azokat összehasonlítja és kiértékeli.

Kulcsszavak: myDAQ, LabVIEW, Összehasonlítás, mérés, adatfeldolgozás.

\section{Mérőrendszer rövid bemutatása}

A dolgozatom alapját az 1. ábrán látható rendszer képezi. A feladat során létrehoztam egy olyan rendszert, amely tartalmaz egy myDAQ mérésadatgyűjtő kártyát, az optikai érzékelőket, a mozgatásért felelős elektronikát, a szükséges tápellátást a különböző eszközök vezérlésére és a kiértékeléshez megírt programot futtató számítógépet. [1]

Sok lehetőség adódott arra, hogy a 2 különböző pályaelemet egymáshoz csatlakoztatva milyen pályaalakot építek ki. Egy pár lehetőség a 2. ábrán látható. Az elképzelésem az volt, hogy összehasonlítom az ember által lejátszott köridőt azzal, amit a gép „futtat” le. Ehhez azonban szükségsze- rü volt egy olyan pálya kiépítése, ahol mind az ember által, mind a vezérlő által irányított pályaszakasz egyforma hosszú.

A feltételnek eleget téve a „8-ast” leíró pályaszakaszt kell megvalósítani.

A megépített „8-as” pályaszakasz két „sint” tartalmaz, amelyen keresztül az versenyautókat irá-

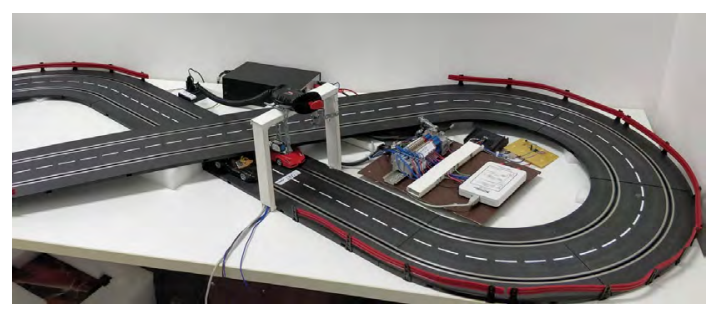

1. ábra. A megépített rendszer 


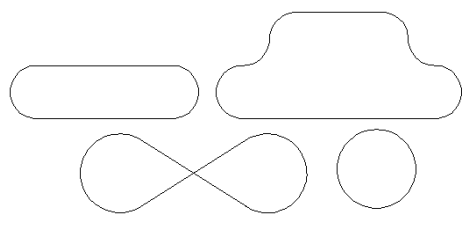

2. ábra. Lehetséges pályakialakítások

nyítottam. Mindegyik versenyautónak a köridejét és az általa megkezdett körök számát egy-egy optikai érzékelő digitális jelének feldolgozásából kaptam. Erről a 3.4. fejezetben tárgyalom még.

\section{A rendszer hardveres felépítése}

A teljes rendszer, amely tartalmazza az összes áramköri elemet a 3. ábrán tekinthető meg.

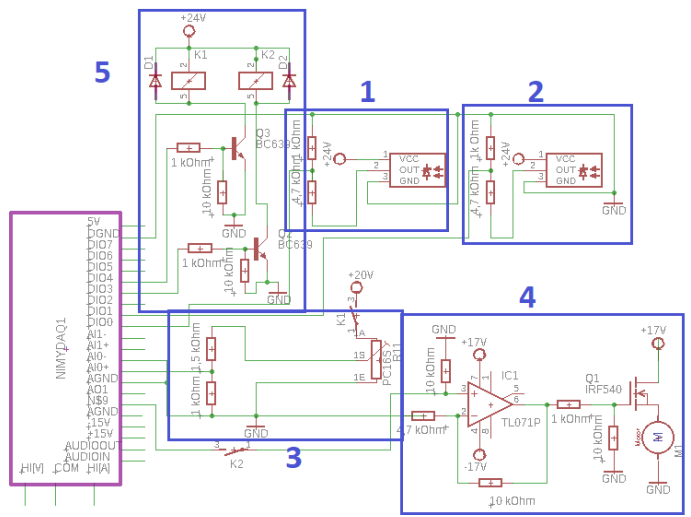

3. ábra. A rendszer sematikus kapcsolási rajza

A fenti ábrán található kapcsolás 5 részre osztható:

- belső pálya tárgyreflexiós fénykapujának áramköre;

- külső pálya tárgyreflexiós fénykapujának áramköre;

- ember által vezérelt pálya áramköre;

- myDAQ adatgyűjtő kártya által kiadott jel áramköre;

- pályavezérlési jelek aktív állapotának vezérlése.

\subsection{Fénykapuk feszültségosztó áramköre}

A belső és külső pálya fénykapuk áramköre ugyanaz, ezért ezeket együtt tárgyalom. Ezek a 3. ábrán az egyes és kettes számmal ellátott bekeretezett részek. Ezeknek lényege egy feszültségosztás. Az érzékelők $24 \mathrm{~V}$ feszültséget továbbítanak a kimeneten, azonban a myDAQ bemeneti egységei TTL logikával müködnek.

$$
\frac{R_{1}}{R_{1}+R_{2}} * U_{\text {é }}=U_{r}
$$

Az (1) egyenlet a feszültségosztás kiszámolására szolgál. Az $\mathrm{R}_{1}$ és $\mathrm{R}_{2}$ az áramkörben használt két ellenállás, az Ué az érzékelő kimenetén megjelenő feszültség, míg az Ur az eredményül kapott „redukált” feszültség. Az $\mathrm{R}_{1}$ ellenállás névleges értéke 1 $\mathrm{k} \Omega$, az $\mathrm{R}_{2}$ ellenállásé pedig $4,7 \mathrm{k} \Omega$.

\subsection{Ember által vezérelt pálya áramköre}

Ez az áramkör a 3. ábrán átható a 3-as számmal ellátott bekeretezett négyzetben található.

A programkód írásának elején a mérésadatgyüjtő kártya DMM bemenetét használtam fel a jel tárolására több indokból is. Az egyik érv a nagy mérési intervallum volt, amivel rendelkezik a port (60 V). A beolvasott feszültség maximális értéke, terheletlen állapotban elérte a 20 voltot is. Abban az esetben, ha analóg bemenetet szerettem volna beolvasni az értékeket, akkor feszültségosztót kellett volna alkalmazni. A DMM bemenet használata, azzal is jár, hogy a mintavételi frekvenciája nagyon kicsi. Az adatáramlási elvből adódik, hogy addig nem fog (újra) lefutni a while ciklus, amíg az abban megírt kódsor mindegyike nem fejeződött be. Ebből fakad az, hogy a ciklusidőt a leglassabb lefutással rendelkező kódsor fogja meghatározni. A DMM port fél másodpercenként vett mintát, s ez lett a ciklusidő is.

Látható a 4. ábrán, hogy 30 szekundum alatt kevés (számszerűen 26) mintát vett a myDAQ eszköz. Így az adatgyűjtő kártya egyik analóg bemenetét használtuk fel a továbbiakban a jobb ciklusidő eléréséért. Ez azonban egy feszültségosztó elhelyezését igényelte a jeladó és vevő között. Ebben az esetben is egy feszültségosztó áramkört kellett használni. Ezt az (1) egyenlettel lehetett számolni. Ebben az esetben egy $1 \mathrm{k} \Omega$-os, és egy 3,7 $\mathrm{k} \Omega$-os ellenállást használtam fel.

\subsection{Adatgyüjtőkártya pályavezérlési áramköre}

Ennek az áramkörnek a szerepe a jelerősítés és teljesítményillesztés. A myDAQ eszköz kimenetén maximálisan $10 \mathrm{~V}$-ot tud kiadni vagy $2 \mathrm{~mA}$-t. Ez a 3. ábrán a négyessel ellátott négyzetben látható. A megépített áramkör erősítése a következő:

$$
A_{U}=\frac{R_{2}}{R_{1}}+1
$$

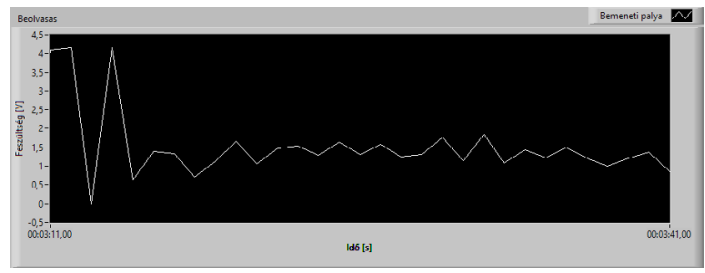

4. ábra. DMM bemenet feszültség-idő diagrammja 


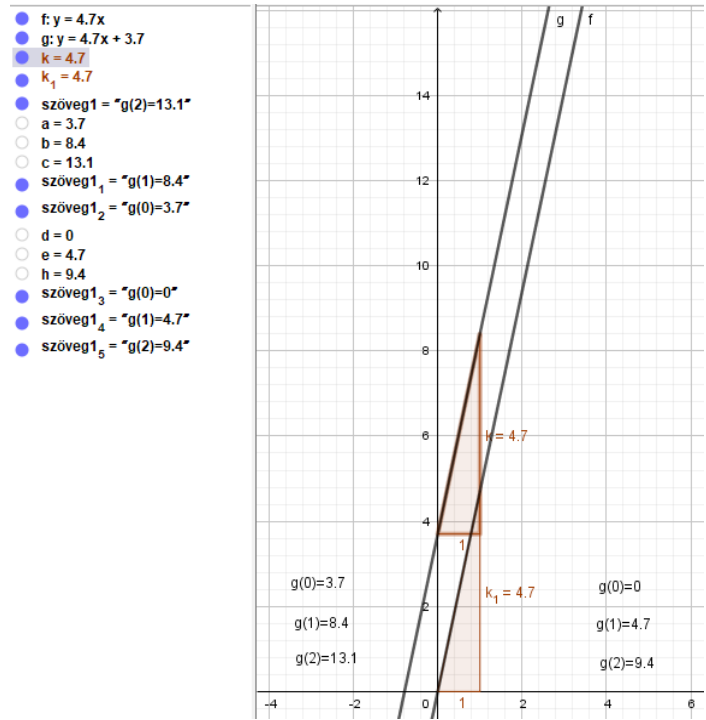

5. ábra. Kimeneti jel ábrázolása eltolással és eltolás nélkül

A (2) egyenletbe behelyettesítve a megfelelő értékeket az erősítési tényezőnek, AU, 5,25 névleges értékét kaptam. Azonban a jel számértékének 4,7-szerese jelenik a pályán, különböző veszteségek miatt. Ez az érték pedig megközelítőleg megegyezik a feszültségosztóéval. Ez azért fontos, hogy azonos linearitású egyenest kapjunk, így a beérkező adatsor reprodukálható legyen a kimeneten. A MOSFET nyitási karakterisztikájából következően egy eltolást kellett betenni a rendszerbe, melynek mértéke 3,7 V. Az 5. ábrán látható a mérésadatgyüjtő kártya kimenetén megjelenő feszültség az erősítés utáni állapota (f függvény) és az „offsetelt”, eltolt (g függvény) egyenes képe is. [2]

\subsection{MyDAQ pályavezérlési jel és a konzol je- lének kontrolálása}

Fennáll annak a lehetősége, hogy a program futásának leállításakor marad feszültség a kimeneten, ami eredményezi azt, hogy a versenyautó nem fog leállni csak a következő alacsony jelszintre amit kapni fog, ezért le kellett választani a kimenetet közvetlenül a pályáról. Ugyan a verseny indítása szoftveresen LED-ekkel (Light Emitting Diode) müködik, de, hogy ne indulhasson hamarabb a versenyző egy kicsivel sem, így a bemenetet, a potenciométer jelét is egy digitális jelhez kötöttem. Ezt egy-egy BC639 típusú tranzisztorral oldottam meg, ami a kimeneti LVTTL jelre kapcsol. Ez az áramkör az 5-ös számmal ellátott bekeretezett részben található a 3 . ábrán.

\section{A rendszer szoftveres felépítése}

A szoftver felépítéséhez NI LabVIEW 2015 verziójú programot használtam fel. A rendszer kommunikációja a 6. ábrán látható. [3]

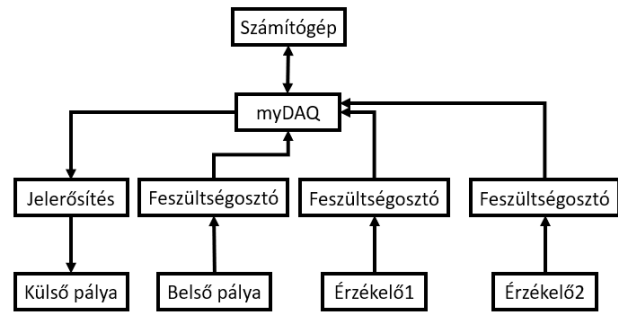

6. ábra. A megépített rendszer kommunikációja

A szoftveres felépítés tartalmaz egy blokk diagrammot -ahol található a program felépítése, VIok kapcsolata, a programkód- és egy front panel részt, amely olyan feladatot lát el, mint egy HMI (Human Machine Interface). [4]

Tab control funkció segítségével 3 részre tagoltam a front panelt. Az első tájékoztató jellegű, ami a verseny menetét, szabályait, fogalmazza meg. A második lap -ami egyben a főoldal is- verseny elindításáról, pillanatnyi feszültségértékekről, köridőkről ad visszajelzést (7. ábra), míg a harmadik egy a verseny kiértékeléséről szóló oldal.

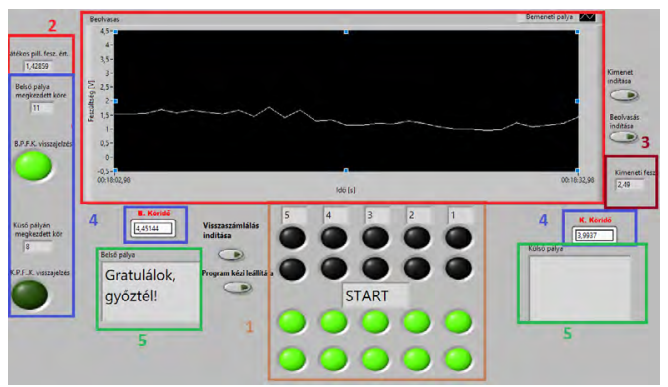

7. ábra. Front panel fö oldala

\subsection{Verseny indítása}

Ez a rész a 7. ábrán barna színnel és 1-es megjelöléssel látható. A program a „visszaszámlálás indítása” feliratú gomb megnyomásával indítható el. Ennek a jelnek a hatására a felső fekete LED-ek párosával pirossal kezdenek világítani, és minden 800 ms letelte után ismét két LED kapcsol. Mindegyik fölött megjelenik egy számláló is ami a hátralévő LED-ek számát jelzi, majd miután mindegyik piros világít, az alsó 10 LED kezd el zölden világítani, és egy „START” felirat is megjelenik, ami indítja a versenyt.

\subsection{Adatbeolvasás}

Abban a pillanatban ahogy a zöld LED-ek világítani kezdenek elindul az bemenő adatok rögzítése. 
Az adatok beolvasásának inicializáló részénél először is létrehoztam a mappát, meghatároztam a mentési helyet, fájl nevét („beolvasott_fesz_ertek”_év_hónap_nap), kiterjesztésé(,.lvm”), majd ehhez hozzárendeltem azokat az információkat, amiket majd el akartam menteni (,idő”, „beolvasott_feszültség_ertek”) . Miután a program létrehozta a mappát, a beállításoknak megfelelően, adott pillanatban elkezdi tárolni az adatokat. Az éppen aktuális időpillanathoz hozzárendel mindig egy feszültségértéket.

\subsection{Adatsorból visszaolvasott vezérlő jel}

A kimeneti jelnek az alapja egy már beolvasott feszültség adatsor vagy egy előre megírt program, amely a pályát 2 főrészre osztja és ezek alapján váltogatja a feszültségértékeket. Matematikai átalakítást hajtottam végre az adott adatsoron, hogy a már amúgy is jó köridőt javítsam. Ezt szorzó tényezővel hoztam létre. A felhasznált MOSFET offset hibáját is itt, szoftveresen javítottam. Azonban mivel a MOSFET-ig be volt építve egy erősítés is, ezért a korrekciónál az erősítést is figyelembe kellett venni. A program a kiírni kívánt adattömböt először elemekre bontja, elvégzi a matematikai korrekciókat, majd újra tömbbé alakítja a kiíratás és a kiértékelés miatt. [5]

\subsection{Köridő mérő és számláló programok}

Amikor a bemeneten megjelenik a jel a program léptet a számlálón egyet. Időzítő azért van elhelyezve a számlálással egy időben, mivel a program mintavételezési frekvenciája, az autó lassú elhaladásához viszonyítva gyors, így többet léptetett a számlálón egy egységnél. Annak érdekében, hogy ezt elkerüljem, egy 300 ms időzítést építettem be. Mindegyik szenzornak külön számlálója van értelemszerűen, s akkor áll le a program, ha ezek közül valamelyik eléri a tizenegyedik kört. A számlálók a megkezdett köröket mutatják, azaz a megtett körök száma 10. Ennyit kört tartalmaz egy „futam”.

A köridők mérésekor a program az érzékelő felfutó éleit figyeli. Amikor az érzékelő jele elsőnek megjelenik a digitális bemeneten akkor elindul egy számláló egészen addig ameddig újból nem érzékel a szenzor. Abban a pillanatban amikor a jel újra megjelent a bemeneten az addig eltelt időt tömbben tárolja, majd újra indítja a számlálót. Ez a folyamat egészen addig fut le újra és újra míg valamelyik érzékelő számlálója el nem éri a 11. megkezdett kört.

\section{Verseny kiértékelése}

A legutolsó rész a kiértékelés. Attól függően, hogy egy visszaolvasott adatsor vagy az érzékelők

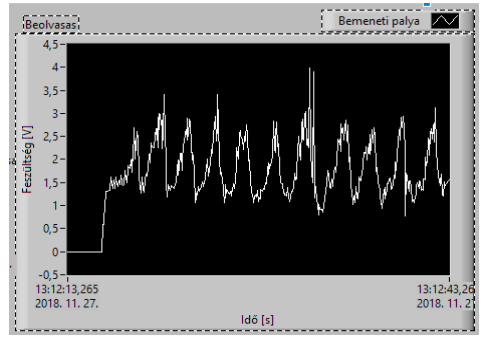

8. ábra. Kiértékelt feszültség-idő diagram

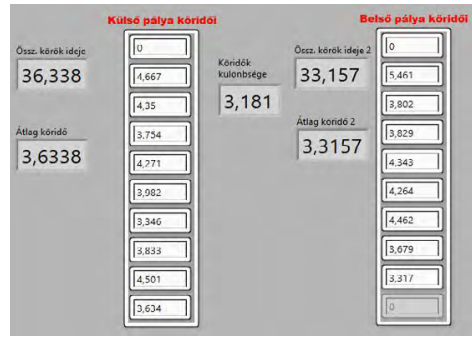

9. ábra. Köridők kiértékelése

által generált jel az amelyik ellen zajlik a verseny, kapunk diagrammban visszajelzést, amely a feszültséget ábrázolja az idő függvényében. [6]

Ezek mellett a kiértékeléshez tartozik a köridők részletes ismertetése. A köridőket egy tömbbe gyűjti a program, majd azt összeadja a benne lévő elemeket. Így kapjuk meg azt az időt, ami a 10 teljes kör megtételéhez kellett. Az átlag köridőt úgy kaptam meg, hogy az előbb említett időt elosztjuk a körök számával. Végül pedig a program kiszámolja, hogy mennyi volt a lemaradása a vesztesnek a győzteshez képest.

\section{Szakirodalmi hivatkozások}

[1] Tóth J., Tóth E., Mezei G.: Automtic car park control with HMI and PLC. Annals of the University of Oradea Fascicle of Management and Technological Engineering 11/21. (2012) 2.115-2.121.

[2] http://www.alldatasheet.com/datasheet-pdf/ pdf/52968/FAIRCHILD/IRF740.html (letöltve: 2018.10.20.)

[3] Ács V., Tóth J.: Test station for Reed Sensors and Inductive Proximity Switches. Annals of the University of Oradea Fascicle of Management and Technological Engineering 16/26. (2017). 99-104.

[4] Sipos K., Tóth J.: Elektropneumatikus szelepek áramlási veszteségének mérése ipari eszközökkel. Műszaki és Menedzsment Tudományi Közlemények 2/1. (2017) 68-72.

http://ijems.lib.unideb.hu/file/9/58edf7d02f0e9/ szerzo/2017113.PDF

[5] Tóth J:: Automatika. 1. kiadás, TERC KFT., 2013. 17-27.

[6] Tóth J., Kocsis I.: Mérési, irányitási és diagnosztikai módszerek a sporteszközök alkalmazása során. Debrecen, Magyarország: Debreceni Egyetem Műszaki Kar (2015) ISBN: 9789634738954 